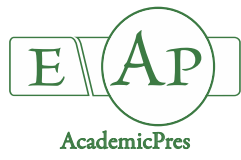

\title{
The Effect of Genotype, Climatic Conditions and Nitrogen Fertilization on Yield and Grain Protein Content of Spring Wheat (Triticum aestivum $\mathbf{L}$.)
}

\author{
Rozalia KADAR ${ }^{1}$, Leon MUNTEAN ${ }^{2 *}$, Ionuț RACZ ${ }^{1}$, Andreea D. ONA², \\ Adrian CECLAN ${ }^{1}$, Diana HIRIŞCĂU ${ }^{1}$ \\ ${ }^{1}$ Agricultural Research and Development Station Turda, 27 Agriculturii, Turda, Cluj, Romania; rozalia.kadar@scdaturda.ro; \\ ionut.racz@scdaturda.ro; adrian.ceclan@scdaturda.ro;diana.hriscau@scdaturda.ro \\ ${ }^{2}$ University of Agricultural Sciences and Veterinary Medicine, Faculty of Agriculture, Department of Plant Culture, 3-5 Calea Mănăştur, \\ 400372,Cluj-Napoca,Cluj,Romania; leon.muntean@usamvcluj.ro ( ${ }^{*}$ correspondingauthor); andreea.ona@usamvcluj.ro
}

\begin{abstract}
Cultivation of spring wheat varieties has expanded into areas with abundant winters where winter wheat is not suitable. Due to lack of research in Romania regarding the influence of different factors on hard red spring wheat, the present study aimed at a better understanding of the influence of genotype, climatic conditions and nitrogen fertilization on the spring wheat yield and quality, and to analyse the correlations between grain yield and grain protein content. Experiences were conducted from 2015 to 2018 on two levels of $\mathrm{N}$ fertilization (50 and $100 \mathrm{~kg} \mathrm{ha}^{-1}$ ) at Agricultural Research and Development Station Turda. Biological material consisted of 19 genotypes, four of local origin and fifteen of foreign origin, from three different varieties (ferrugineum, lutescens, erythrospermum). The results indicate that the three experimental years were more important in the interactions with the genotypes than was the $\mathrm{N}$ fertilization, for both yield and protein content. The most productive cultivars with good stability were 'Feeling' and 'SG 5-01', and the most valuable varieties regarding the protein content were 'Pădureni', 'Corso' and 'GK Tavasz'. A high dose of N assured a high yield and good quality for all cultivars. Although negative correlations were found between production and protein content in HRSW, there were found cultivars that show positive regressions of protein content, such as 'Pădureni', 'Feeling' and 'Lona'.
\end{abstract}

Keywords: correlation; erythrospermum; ferrugineum; hard red spring wheat; lutescens; stability

\section{Introduction}

Wheat is one of the most important food crops in the world (Gyarmati, 2017); about 21\% of the world's food depends on wheat crops, which grow on 220 million hectares worldwide, representing about $30 \%$ of the global harvested cereal area (FAO, 2018). Out of this surface $70 \%$ is represented by winter wheat, and the rest of it by spring wheat.

Classification into spring or winter wheat is common, and traditionally refers to the season during which the crop is grown (Wang et al., 2018). Winter wheat is sown in autumn and requires a period of cold winter temperatures $\left(0{ }^{\circ} \mathrm{C}\right.$ to $\left.5^{\circ} \mathrm{C}\right)$ for ear formation. Spring wheat is usually sown in the spring and matures in late summer, but can be sown in autumn in countries that experience mild winters.

Due to the introduction of spring wheat varieties, the wheat cultivated area has been extended to the north, in areas with heavy winters, where winter wheat is not suitable. Thus, very early spring wheat varieties have been created in Canada with a vegetation period of less than 100 days, suitable for northern culture areas at latitude above $60^{\circ}$ (Clarke et al., 1997; DePauw et al., 2000; Fox et al., 2013).

Although world food needs are increasing, climate changes, such as rise in temperature and decline in rainfall may negatively affect crop yields in some major production regions of the world (Licker, 2013). Few studies have been conducted to assess the long-term impact of climate change on spring wheat production. A better understanding of how spring wheat responds to regional climatic conditions is essential for adapting the farming practices to take advantage of local conditions (Hoffmann and Sgrò, 2011; Hawkesford et al., 2013). 
516

To cope with climate change, The Global Wheat Breeding Program at CIMMYT was founded to explore strategies for breeding widely adapted and highly stable wheat cultivars (Braun et al., 1996; Singh and Trethowan, 2007). Farmers need wheat varieties that can cope with a highly variable climate, such as varieties with high yield potential to take advantage of rain and irrigation when available and also with heat and drought tolerance in hot years (Abayomi and Wright, 1999).

Temperature, solar radiation and relative air humidity were major climatic factors that affected the yields of spring wheat (Zhao et al., 2017). Furthermore, the effect of the average minimum temperature on yield was greater than that of the average maximum temperature. According to Hatfield et al. (2011), temperature rising above 25 to $35^{\circ} \mathrm{C}$ would shorten the grain-filling period and reduce wheat yield.

Nitrogen fertilization is the main factor and an indicator of the effectiveness of agricultural production. Spring wheat $\mathrm{N}$ requirements are high during tillering, stem elongation, booting, heading, and grain filling, for reproductive organ development and for increased protein accumulation in kernel (Delogu et al., 1998).

The importance of efficient $\mathrm{N}$ fertilization for yield and quality of spring wheat has been highlighted by many researchers. Among the factors that have a significant impact are the dose of $\mathrm{N}$ fertilization (Jaćimović et al., 2008; Staugaitis et al., 2017) source of $\mathrm{N}$ fertilizer (Jarecki et al., 2017), timing of $\mathrm{N}$ application (Rawluk et al., 2000; Woolfolk et al., 2002; Karamanos et al., 2005), culture rotation (Kaerner, 1999; Halvorson et al., 2000), frequency of rainfall and temperature during the growing season (Zhang and Oweis, 1999). A recommended technique for synchronizing the $\mathrm{N}$ supply with the wheat $\mathrm{N}$ demand is split application of the $\mathrm{N}$ fertilizer (Nyiraneza et al., 2012).

Another important observation is that one of the most relevant quality traits in spring wheat, grain protein concentration, which affects the milling and baking quality of the grain, is also affected by N levels (Gauer et al., 1992; Lopes-Bellido et al., 2001; McKenzie et al., 2006). Previous researches have reported that the maximum protein content is generally attained at $\mathrm{N}$ levels much higher than those required to reach maximum yield (Fowler, 2003).

In order to optimize spring wheat production on different cultivation condition, the identification of stable genotypes, with high and good quality yield, in various environments has been a continuous challenge for plant breeders. The response of each genotype to environmental variations results in different patterns of genotype-byenvironment interaction (Săulescu and Handrea, 1986; Benin et al., 2014; Crespo-Herrera et al., 2017).

Due to the lack of research in Romania regarding the previously presented aspects, our study aimed at a better understanding of the influence of genotype, climatic conditions and nitrogen fertilization on the spring wheat yield and quality, having as objectives (i) to analyses the effect of genotype, year and $\mathrm{N}$ fertilization on spring wheat yield and (ii) to analyses the effect of genotype, year and $\mathrm{N}$ fertilization on spring wheat grain protein content and (iii) to analyses the correlations between the grain yield and the grain protein content in spring wheat.

\section{Materials and Methods}

\section{Climatic conditions}

In 2015, during the spring months, the thermal regime was warm and a little rainy in March, and drought in April (Fig. 1). Seeding the experimental fields in the third decade of March caused rapid and uniform emergence of all experimental variants. Further, the warm heat regime and rainfall in May and June created very favorable conditions for HRSW, with the highest yields.

Although in 2017 no dry periods were recorded during the entire HRSW vegetation period, the obtained yields were lower compared to the previous year, due to the minimum temperatures of $5-6^{\circ} \mathrm{C}$ which coincided with differentiation phenophases of floral primordia.

Year 2018 was the most special in terms of climatic conditions and that is why a more detailed presentation is necessary. January was excessively dry and February normal in terms of precipitation. March was warm and excessively rainy so that it was possible to complete the water deficit in the soil, which in combination with favourable temperatures led to favourable conditions for the sowing of HRSW on March $20^{\text {th }}$. In March and April, alternate periods of higher and lower temperatures, in the range of $11-20$, the minimum temperatures being very low, caused stagnation in the development of the phenophases of HRSW. On April $20^{\text {th }}$, a $3 \mathrm{~cm}$ thick layer of snow covered the soil, and it persisted until the next day. Ear emergence of HRSW began on May $28^{\text {th }}$ and continued, depending on the genotype, until June $8^{\text {th }}$ when the ear of 'T. 265-01' line (alternate) emergenced the last.

\section{Experimental procedures}

Between 2015-2018, a three factor experiment including two levels of $\mathrm{N}$ ( 50 and $100 \mathrm{~kg} \mathrm{~N} \mathrm{ha}^{-1}$ ) and 19 cultivars of hard red spring wheat (HRSW) was conducted in the conditions of the Agricultural Research and Development Station (ARDS) Turda (463' N; 234'ㄹ; $345 \mathrm{~m}$ above Adriatic Sea), which is located in the Transylvanian Plain, Romania.

The experiment was established on a typical clay Chernozem soil, typical for the forest steppe encountered over half of the Transylvanian Plain. The agrochemical indexes for this soil type had the following average values: the soil reaction is neutral $(\mathrm{pH}$ 6.9-7.1) and the humus content is $3.56-3.92 \%$ in the arable layer. The soil is rich in total nitrogen (0.183-0.196\%) and potassium content (249 ppm in Amp), and poor in mobile phosphorus (15 ppm in Amp).

The biological material consisted of 19 genotypes, four of local origin and 15 of foreign origin, from three varieties (Table 1).

Nitrogen fertilization was carried out in one or two stages: the variant $\mathrm{N}_{50}$ and half of $\mathrm{N}_{100}$ was applied in early spring (before straw elongation) and the other half (50 kg ha ${ }^{-1} \mathrm{~N}$ ) before heading.

The plot surface area was $10 \mathrm{~m}^{2}$. Sowing was made in every year during the last decade of March. Plots were harvested individually by combine and grain yield reported at uniform moisture content (14\%). Determination of protein content was performed on the whole grain with Infragrain 9500 analyser. 
Table 1.Biological material used in the experiment

\begin{tabular}{|c|c|c|c|}
\hline No. & Cultivar & Origin & var. \\
\hline 1 & 'Pădureni' & Romania-Turda & ferrugineum \\
\hline 2 & 'Т. 265-01' & Romania-Turda & erythrospermum \\
\hline 3 & 'SG 5-01' & Czech Republic & erythrospermum \\
\hline 4 & 'SG 106-01' & Czech Republic & erythrospermum \\
\hline 5 & 'SG U 773' & Czech Republic & erythrospermum \\
\hline 6 & 'Corso' & Germany & lutescens \\
\hline 7 & 'Lona' & Switzerland & lutescens \\
\hline 8 & 'Feeling' & Lithuania & lutescens \\
\hline 9 & 'Gk Tavasz’ & Hungary & ferrugineum \\
\hline 10 & 'Triso' & Germany & lutescens \\
\hline 11 & 'Broma' & Poland & erythrospermum \\
\hline 12 & 'Beloterkovskaia' & Russia & lutescens \\
\hline 13 & 'Henica' & Poland & lutecens \\
\hline 14 & 'Jara' & Czech Republic & lutescens \\
\hline 15 & 'Jota' & Poland & lutescens \\
\hline 16 & 'Prif $3 '$ & Romania-Fundulea & erythrospermum \\
\hline 17 & 'Prif 4' & Romania-Fundulea & erythrospermum \\
\hline 18 & 'Sigma' & Poland & lutescens \\
\hline 19 & 'Silva' & Poland & lutescens \\
\hline
\end{tabular}

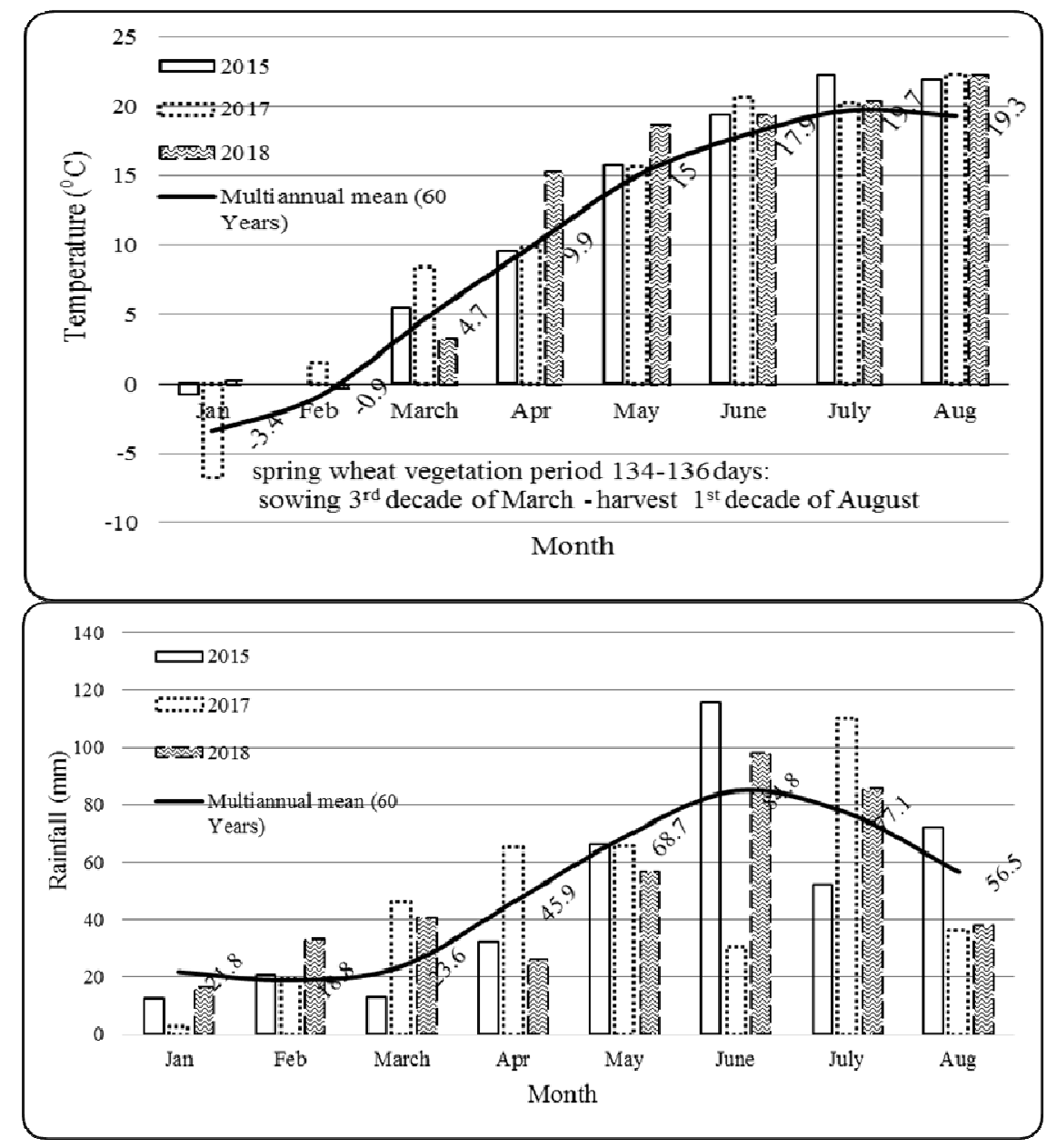

Fig. 1.Temperatures and rainfall regime within the experimental area 
518

\section{Statistical analyses}

Analysis of variance (ANOVA) was used to estimate the main effects of genotype, year (climatic conditions) and nitrogen fertilization, and the interactions among these factors. The intensity of the link between production and content of protein in the three experimental years and fertilization variants was estimated using the correlation coefficient $(\mathrm{r})$.

\section{Results}

\section{Grain yield}

Analysing Table 2 it is noticeable that for grains yield there is variance for the genotype, years, $\mathrm{N}$ fertilization and $G \times Y$ interaction, and no variance among $G \times F$ interaction and $\mathrm{G} \times \mathrm{Y} \times \mathrm{F}$ interaction.

The results of ANOVA indicate that the years were more important in the interactions with the genotypes than was the $\mathrm{N}$ fertilization. The interaction of genotype, year and $\mathrm{N}$ fertilization also showed that the effect of $\mathrm{N}$ fertilization was relatively unimportant for the occurrence variance; this aspect is in accord with other researches (e.g. Ayoub et al., 1995; Cooper et al., 2001 and Ma et al., 2004). In eastern Canada, $\mathrm{Ma}$ et al. (2004) explain the lack of $\mathrm{N}$ fertilization main effect, and $\mathrm{N} x$ environment interaction by due to the high $\mathrm{N}$-supply of soils, as well as the experimental conditions at ARDS Turda.

Fertilisation with $\mathrm{N}_{100}$ presents the highest grain yield, regardless of cultivar or year (Table 3). Our data are in the same range as those in the studies reported by CRAAQ, 2010, which recommended 90 to $120 \mathrm{~kg} \mathrm{~N}$ ha rate for spring wheat in Quebec.

In the climatic years favourable to the wheat crop, 2015 and 2017, the 'Feeling' cultivar provided the highest production, and in 2018 (extreme climatic conditions) the 'SG 5-01' cultivar was noted for the same character. Both varieties have good production stability, showing statistically positive difference as compared with the control (mean of the experiment) for average production over the three experimental years.

Table 2.Analysis of variance on grain yield in the experiment $(19 \times 3 \times 2)$

\begin{tabular}{|c|c|c|c|c|}
\hline Source of variation & Df & MS & F & $\mathrm{P}$ \\
\hline Genotype (G) & 18 & 289.580 & 27.165 & 0.0001 \\
\hline Year $(\mathrm{Y})$ & 2 & 6114.021 & 178.763 & 0.0001 \\
\hline $\mathrm{N}$ fertilizers $(\mathrm{F})$ & 1 & 3694.082 & 66.675 & 0.0001 \\
\hline $\mathrm{G} \times \mathrm{Y}$ interaction & 36 & 82.792 & 7.767 & 0.0001 \\
\hline $\mathrm{G} \times \mathrm{F}$ interaction & 18 & 12.356 & 1.159 & NS \\
\hline $\mathrm{G} \times \mathrm{Y} \times \mathrm{F}$ interaction & 36 & 15.389 & 1.444 & NS \\
\hline Error A & 4 & 34.202 & & \\
\hline Error F & 6 & 55.404 & & \\
\hline Error $S$ & 216 & 10.660 & & \\
\hline
\end{tabular}

Table 3.Average grain yields (kg ha-1) obtained in HRSW cultivars, on two levels of nitrogen fertilization (ARDS Turda, 2015-2018)

\begin{tabular}{|c|c|c|c|c|c|c|c|c|}
\hline \multirow{2}{*}{ Cultivar } & \multicolumn{2}{|c|}{2015} & \multicolumn{2}{|c|}{2017} & \multicolumn{2}{|c|}{2018} & \multicolumn{2}{|c|}{ Average of $\mathrm{N}$ fertilisation } \\
\hline & $\mathrm{N}_{50}$ & $\mathrm{~N}_{100}$ & $\mathrm{~N}_{50}$ & $\mathrm{~N}_{100}$ & $\mathrm{~N}_{50}$ & $\mathrm{~N}_{100}$ & $\mathrm{~N}_{50}$ & $\mathrm{~N}_{100}$ \\
\hline 'Pădureni' & 5,387 & 6,657 & $4,203^{000}$ & 5,460 & $3,600^{\circ 00}$ & $4,243^{\circ 00}$ & $4,397^{\circ 0}$ & 5,453 \\
\hline 'Т. 265-01' & 5,800 & 6,283 & 5,330 & 5,930 & 4,177 & 5,203 & 5,102 & 5,805 \\
\hline 'Sg 5-01' & 6,267 & 7,140 & $6,003^{* *}$ & $6,407^{*}$ & $5,213^{\prime \prime}$ & $5,923^{\prime \prime}$ & $5,828^{\circ}$ & $6,490^{\circ}$ \\
\hline 'Sg 106-01' & 6,343 & 7,097 & 5,380 & 5,780 & $5,453^{* *}$ & $6,007^{\prime \prime}$ & $5,725^{\circ}$ & 6,295 \\
\hline 'Sg U 773' & 5,723 & 6,917 & 5,520 & 5,853 & 4,813 & 5,577 & 5,352 & 6,116 \\
\hline ‘Corso’ & $4,763^{\circ 00}$ & $5,650^{\circ 00}$ & 5,137 & 5,513 & $5,107^{\circ}$ & 5,447 & 5,002 & 5,537 \\
\hline 'Lona' & 5,720 & 6,987 & $5,683^{\circ}$ & 6,080 & 4,840 & 5,840 & 5,414 & 6,302 \\
\hline 'Feeling' & $6,947^{*}$ & 8,010 ** & $5,920^{\prime \prime}$ & $6,320^{\circ}$ & 4,597 & 5,313 & $5,821^{*}$ & $6,548^{*}$ \\
\hline 'Gk Tavasz’ & 6,093 & 6,343 & $3,867^{\circ 00}$ & 5,227 & 4,587 & 4,863 & 4,849 & 5,478 \\
\hline 'Triso' & 5,910 & 6,970 & 5,607 & 6,007 & 5,377 & 5,737 & 5,631 & 6,238 \\
\hline 'Broma' & 5,763 & 6,260 & 5,440 & 6,120 & 4,910 & 5,210 & 5,371 & 5,863 \\
\hline 'Beloterkovskaia' & 6,030 & 6,387 & 4,963 & 5,330 & 4,887 & 5,030 & 5,293 & 5,582 \\
\hline 'Henica' & 5,530 & 6,450 & 4,647 & $5,047^{\circ}$ & 3,377 & 4,033 & $4,518^{\circ}$ & $5,177^{\circ}$ \\
\hline 'Jara' & 5,797 & 6,517 & 4,663 & $5,070^{\circ}$ & 4,333 & 4,513 & 4,931 & 5,367 \\
\hline 'Jota' & $6,623^{\prime \prime}$ & 7,163 & 5,023 & 5,423 & 3,790 & 4,997 & 5,145 & 5,861 \\
\hline 'Prif 3' & 5,570 & 6,423 & 5,090 & 5,623 & 4,707 & 5,197 & 5,122 & 5,748 \\
\hline 'Prif 4' & 5,363 & 6,423 & 4,870 & 5,273 & 4,177 & 4,937 & 4,803 & 5,544 \\
\hline 'Sigma’ & 5,967 & 6,607 & 4,620 & $5,023^{\circ}$ & 3,610 & 4,873 & 4,732 & 5,501 \\
\hline 'Silva' & 5,933 & 6,517 & 5,117 & 5,517 & 3,913 & 4,800 & 4,988 & 5,611 \\
\hline Mean of experience - control & 5,870 & 6,674 & 5,110 & 5,632 & 4,498 & 5,144 & 5,159 & 5,817 \\
\hline Average of year & & & & & & & & \\
\hline
\end{tabular}


Although fertilization with $\mathrm{N}_{100}$ provided the highest yields, there were also certain varieties 'SG 106-01', 'Corso' (2018 - unfavourable conditions), 'Jota' and 'Lona' (2015 favourable conditions) that performed better under conditions of $\mathrm{N} 50$ fertilization.

The Romanian 'Pădureni' variety, created at ARDS Turda, has an acceptable yield potential, assimilates nitrogen well, but under the unfavourable climatic conditions of 2018, did not performed well. The alternative 'T. 265-01' line, also created at Turda, exceeds the 'Pădureni' variety for production and stability, being a good alternative for its replacement in culture.

\section{Protein content of grains}

Analysis of variance for grain protein content showed there was variance for the same factors as in the case of the yield: genotype, years, $\mathrm{N}-$ fertilisation and $\mathrm{G} \times \mathrm{Y}$ interaction. For $\mathrm{G} \times \mathrm{F}$ and $\mathrm{G} \times \mathrm{Y} \times \mathrm{F}$ interaction there was also no variance (Table 4). These results prove that the interaction between genotype and year is the most important in the occurrence of variance for this HRSW character.

Table 4.Analysis of variance on grain yield in the experience $(19 \times 3 \times 2)$

\begin{tabular}{ccccc}
\hline Source of variation & Df & MS & $F$ & $P$ \\
\hline Genotype $(\mathrm{G})$ & 18 & 7.870 & 126.113 & 0.0001 \\
Year $(\mathrm{Y})$ & 2 & 243.411 & 642.361 & 0.0001 \\
$\mathrm{~N}$ fertilizers $(\mathrm{F})$ & 1 & 238.334 & 2369.481 & 0.0001 \\
$\mathrm{G} \times$ Y interaction & 36 & 1.283 & 20.561 & 0.0001 \\
$\mathrm{G} \times$ F interaction & 18 & 0.283 & 4.540 & NS \\
$\mathrm{G} \times \mathrm{Y} \times$ F interaction & 36 & 0.175 & 2.805 & NS \\
Error A & 4 & 0.378 & & \\
Error F & 6 & 0.100 & & \\
Error S & 216 & 0.062 & & \\
\hline Note: NS - not significant at the $\mathrm{P} \leq 0.05$ level. & & & &
\end{tabular}

Table 5.Grain protein content (\%) in HRSW cultivars, on two levels of nitrogen fertilization (ARDS Turda, 2015-2018)

\begin{tabular}{|c|c|c|c|c|c|c|c|c|}
\hline \multirow{2}{*}{ Cultivar } & \multicolumn{2}{|c|}{2015} & \multicolumn{2}{|c|}{2017} & \multicolumn{2}{|c|}{2018} & \multicolumn{2}{|c|}{ Average of $\mathrm{N}$ fertilization } \\
\hline & $\mathrm{N}_{50}$ & $\mathrm{~N}_{100}$ & $\mathrm{~N}_{50}$ & $\mathrm{~N}_{100}$ & $\mathrm{~N}_{50}$ & $\mathrm{~N}_{100}$ & $\mathrm{~N}_{50}$ & $\mathrm{~N}_{100}$ \\
\hline 'Pădureni' & 13.6 & 16.0 & 10.6 & 13.3 & 12.8 & 14.1 & $12.3^{\circ}$ & $14.5^{\prime \prime}$ \\
\hline 'T. 265-01' & 12.8 & $15.4^{* *}$ & $10.2^{\circ}$ & $12.8^{*}$ & 12.4 & 14.3 & 11.8 & $14.2^{*}$ \\
\hline 'Sg 5-01' & 12.0 & 13.4 & 9.1 & 11.4 & 12.1 & $13.0^{\circ}$ & 11.1 & 12.6 \\
\hline 'Sg 106-01' & 12.5 & 13.5 & 9.9 & 12.4 & $11.9^{\circ}$ & $12.8^{\circ o}$ & 11.4 & 12.9 \\
\hline 'Sg U 773' & 12.5 & 13.4 & 9.6 & 12.0 & 12.3 & 13.5 & 11.5 & 13.0 \\
\hline 'Corso' & 14.2 & $16.2^{* *}$ & 10.4 & $13.0^{*}$ & $13.9^{\cdots *}$ & $15.0^{\cdots *}$ & $12.8^{* *}$ & $14.7^{\cdots}$ \\
\hline 'Lona' & 12.6 & 14.1 & 9.6 & 12.0 & 12.6 & 13.6 & 11.6 & 13.2 \\
\hline 'Feeling' & 12.7 & 13.7 & 9.2 & 11.5 & 12.2 & $12.9^{\circ}$ & 11.4 & 12.7 \\
\hline 'Gk Tavasz' & $14.1^{\cdots}$ & $15.5^{* *}$ & $10.9^{\cdots *}$ & 13.6 & $13.7^{*}$ & 14.6 & $12.9^{\cdots}$ & 14.6 \\
\hline 'Triso' & 12.2 & 13.9 & 9.1 & 11.4 & 12.8 & 14.4 & 11.4 & 13.2 \\
\hline 'Broma' & 12.4 & 13.9 & 9.3 & 11.6 & 12.5 & 13.4 & 11.4 & 13.0 \\
\hline 'Beloterkovskaia' & 12.3 & 14.2 & 9.1 & 11.4 & 13.2 & $14.7^{*}$ & 11.5 & 13.4 \\
\hline 'Henica' & 12.4 & 14.0 & 9.8 & 12.3 & 12.7 & 13.8 & 11.6 & 13.4 \\
\hline 'Jara' & $11.3^{\circ o}$ & $13.1^{\circ 0}$ & 9.0 & 11.3 & $13.3^{*}$ & $14.5^{\circ}$ & 11.2 & 13.0 \\
\hline 'Jota' & $11.0^{\circ 000}$ & $13.3^{\circ}$ & $8.5^{\circ 0}$ & $10.6^{000}$ & 12.4 & 13.7 & 10.6 & 12.5 \\
\hline 'Prif 3' & 12.2 & $13.3^{\circ}$ & 9.2 & 11.5 & $11.8^{\circ}$ & $13.0^{\circ}$ & 11.1 & 12.6 \\
\hline 'Prif 4' & 12.4 & 13.6 & 9.3 & 11.6 & 12.3 & 13.3 & 11.3 & 12.8 \\
\hline 'Sigma' & $11.2^{000}$ & 13.4 & $8.7^{\circ}$ & $10.9^{\circ 0}$ & 12.2 & 13.8 & $10.7^{\circ}$ & 12.7 \\
\hline 'Silva' & $11.3^{\mathrm{oo}}$ & $12.9^{\circ o}$ & 9.0 & 11.4 & $11.5^{\mathrm{oo}}$ & $12.7^{\circ 0}$ & $10.6^{\circ \circ}$ & $12.3^{\circ o}$ \\
\hline $\begin{array}{c}\text { Mean of experience -- } \\
\text { control }\end{array}$ & 12.4 & 14.0 & 9.5 & 11.9 & 12.6 & 13.7 & 11.5 & 13.2 \\
\hline Average of year & & & & & & & & \\
\hline
\end{tabular}

The low temperatures which coincided with floral primordia differentiation phenophases in 2017, influenced the grain protein content of HRSW (Koga et al., 2015), because the highest values for this character were recorded in the years 2015 and 2018. As well as in the production, high nitrogen fertilization increased the protein content of the grains (Table 5). Our data are in line whit previous studies which showed that higher $\mathrm{N}$ rates are very important to increase grain protein concentrations for all spring wheat varieties studied by Ma et al. (2004). Nyiraneza (2012) prove the same fact, that the split application of $\mathrm{N}$ fertilizer at a rate of $120 \mathrm{~kg} \mathrm{~N} \mathrm{ha}^{-1}$ was sufficient to maximize yield and attain the grain protein content level needed for the maximum price premium.

Regardless of the climatic conditions and the $\mathrm{N}$ fertilization dose, 'Pădureni', 'Corso' and 'GK Tavasz' varieties performed better as compared to the other varieties in all experimental years.

A particular case for the protein content was the 'Jara' cultivar, which showed statistically negative differences compared to the experience average (control) in 2015, the favourable year for HRSW and statistically positive 


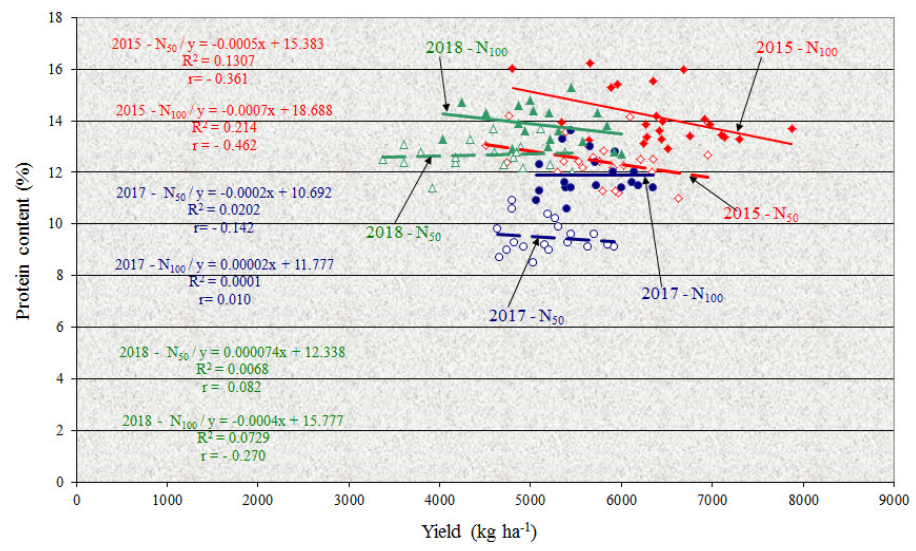

Fig. 2. Correlation between yield and protein content on HRSW

differences in 2018, year with extreme climatic conditions. Probably the low temperature alternation with the high temperatures of that year has positively influenced the accumulation of protein, irrespective of the fertilization dose. 'Beloterkovskaia' and 'Triso' are also two varieties that in 2018 reached high protein content in condition of $\mathrm{N}_{100}$ fertilization, although in the favourable years did not show statistically assured differences.

'Pădureni' variety had the high protein content regardless of the dose of $\mathrm{N}$; the other variety created at ARDS Turda, 'T. 265-01', had a good response of this character only at high doses of $\mathrm{N}$. Both varieties had good stability for quality, not being influenced by climatic conditions.

Although negative correlations were found between the yield and the protein content in HRSW, the regression analysis shows that only a small part of the variation in protein content can be attributed to the variation in production, which gives the possibility of overcoming this obstacle (Fig. 2).

Genotypes that show positive regressions of protein content, such as 'Pădureni', are an argument in this respect, a variety that has an acceptable production potential, being a solution for expanding the areas cultivated with HRSW in Romania, to this date. Two other genotypes: 'Feeling' and 'Lona', which are very productive and have quality indices that correspond to the bakery industry, have been noted in this study.

The 'T. 265-01' alternative wheat line, which is sown in spring (March), presents quality indices close to 'Pădureni', being more productive than it. This line can replace it in the near future, taking into consideration the growing demand for seed of HRSW varieties and ARDS Turda is the only bidder among the breeding centres in Romania for this species.

\section{Conclusions}

The present research concluded that years were more important in the interactions with genotypes than the $\mathrm{N}$ fertilization, for both studied characters. Higher application of $\mathrm{N}$ assured high yields and good protein content for all studied cultivars, but there were also certain varieties, 'SG 106-01', 'Corso', 'Jota' and 'Lona', that behaved well under conditions of $\mathrm{N}_{50}$ fertilization. The most productive cultivars, with good stability of yield, were 'Feeling' and 'SG 5-01'; the most valuable varieties regarding the protein content were 'Pădureni', 'Corso' and 'GK Tavasz'. Negative correlations were found between the production and the protein content in HRSW ( 4 out of 6 cases), but also were found some cultivars that showed positive regressions of protein content: 'Pădureni', 'Feeling' and 'Lona'.

\section{References}

Abayomi YA, Wright D (1999). Effects of water stress on growth and yield of spring wheat (Triticum aestivum L.) cultivars. Tropical Agriculture 76(2):120-125.

Ahmed M, Hassan FU, Razzaq A, Akram MN, Aslam M, AhmadS, Zia-ul$\mathrm{Haq} \mathrm{M}$ (2011). Is photothermal quotient determinant factor for spring wheat yield?. Pakistan Journal of Botany 43(3):1621-1622.

Ayoub M, Guertin S, Smith DL (1995). Nitrogen fertilizer rate and timing effect on bread wheat protein in eastern Canada. Journal of Agronomy and CropScience 174(5):337-349.

Benin G, Storck L, Marchioro VS, Todeschini MH, Milioli AS, Woyann LG (2014). Effects of years, locations and sowing date on the spring wheat yield performance. Revista de la Facultad de Agronomía, La Plata 113:165-173.

Braun HJ, Rajaram S, Van Ginkel M (1996). CIMMYT's approach to breeding for wide adaptation. Euphytica 92(1-2):175-183.

Clarke JM, Depauw RM, Mccaig TN, Fernandez MR, Knox RE, Mcleod JG (1997). AC Elsa hard red spring wheat. Canadian Journal of Plant Science 77(4):661-663.

Cooper M, Woodruff DR, Phillips IG, Basford KE, Gilmour AR (2001). Genotype-by-management interactions for grain yield and grain protein concentration of wheat. Field Crops Research 69(1):47-67.

CRAAQ (2010). Guide de référence en fertilisation [Reference guide of fertilization]. 2nd ed. Centre de référence en agriculture et agroalimentaire du Quebec, Ste-Foy, QC, Canada.

Crespo-Herrera LA, Crossa J, Huerta-EspinoJ, Autrique E, Mondal S, Velu G, Vargas M, Braun HJ, Singh RP (2017). Genetic yield gains In CIMMYT s international elite spring wheat yield trials by modeling the genotype $\times$ environment interaction. CropScience 57(2):789-801. 
Delogu G, Cattivelli L, Pecchioni N, De Falcis D, Magiore T, Stanca AM (1998). Uptake and agronomic efficiency of nitrogen in winter barley and winter wheat. European Journal of Agronomy 9(1):11-20.

DePauw RM, Clarke JM, Knox RE, Fernandez MR, Mccaig TN, Mcleod JG (2000). AC Abbeyhard red spring wheat. Canadian Journal of Plant Science 80(1):123-127.

Food and Agriculture Organization (2018). Faostat database, http://faostat.fao.org/beta/en/ (accessed 20 August 2018).

Fowler DB (2003). Crop nitrogen demand and grain protein concentration of spring winter wheat. Agronomy Journal 95(2):260-265.

FoxSL, Wise IL, Smith MAH, Humphreys DG, Brown PD, et al.,Niziol D (2013). Shaw hard red spring wheat. Canadian Journal of Plant Science 93:299-305.

Gauer LE, Grant CA, Geul DT, Bailey LD (1992). Effects of nitrogen fertilization on grain protein content, nitrogen uptake, and nitrogen use efficiency of six spring wheat cultivars, in response to estimated moisture supply. Canadian Journal of Plant Science 72(1):235-241.

Gyarmati G, 2017. On what factors the wheat production and price depends. Management, Enterprise and Benchmarking in the $21^{\mathrm{s}}$ Century IV:78-96.

Halvorson AD, Black AL, Krupinsky JM, Merrill SD, Wienhold BJ, Tanaka DL (2000). Spring wheat response to tillage and nitrogen fertilization in rotation with sunflower and winter wheat. Agronomy Journal 92(1):136-144.

HatfieldJL, Boote KJ, Kimball BA, Ziska LH, Izaurralde RC, et al., Wolfe D (2011). Climate impacts on agriculture implications for crop production. Agronomy Journal 103(2):351-370.

Hawkesford MJ, ArausJL, Park R, Calderini D, Miralles D, et al., Parry MAJ (2013). Prospects of doubling global wheat yields. Food and Energy Security 2(1):3448.

Hoffmann AA, Sgrò CM (2011). Climate change and evolutionary adaptation. Nature 470(7335):479-485.

Jaćimović G, Malešević M, Marinković B, Crnobarac J, Latković D, Šeremešić S, Milošev D (2008). Spring wheat yield components depending of nitrogen, phosphorus and potassium fertilizing rates. Godina 32(I):57-63.

Jarecki W, BuczekJ, Bobrecka-Jamro D (2017). Response of spring wheat to different soil and foliar fertilization. Journal of Central European Agriculture 18(2):460-476.

Kaerner E, Kaerner M (1999). The influence of nitrogen fertilizer and preceding crop on the gluten content of spring wheat. AGRIS 6:59-62.

Karamanos RE, Flore NA, Harapiak JT (2005). Effect of post emergence nitrogen application on the yield and protein content of wheat. Canadian Journal of Plant Science 85(2):327-342.

Kogaa S, Böcker U, Moldestad A, Tosi P, Shewry PR, Mosleth EF, Kjersti Uhlen A (2012)). Influence of temperature on the composition and polymerization of gluten proteins during grain filling in spring wheat (Triticum aestivum L.).Journal ofCereal Science 65:1-8.
Licker R, Kucharik CJ, Dore'T, Lindeman MJ, Makowski D (2013). Climatic impacts on winter wheat yields in Picardy, France and Rostov, Russia: 1973-2010. Agricultural and Forest Meteorology 176:25-37.

Lopes-Bellido L, Lopes-Bellido RJ, Castillo JE, Lopes-Bellido FJ (2001). Effects of long-term tillage, crop rotation, and nitro-gen fertilization on bread-making quality of hard red spring wheat. Field Crops Research 72(3):197-210.

MaBL, Yan W, Dwyer LM, Fregeau-Reid J, Voldeng HD, Dion Y,Nass H (2004). Graphic analysis of genotypes, environment, nitrogen fertilizer and their interaction on spring wheat yield. Agronomy Journal 96(1):169-180.

McKenzie RH, Bremer E, Grant CA, Johnston AM, DeMulder J, Middleton $\mathrm{AB}$ (2006). In-crop application effect of nitrogen fertilizer on grain protein concentration of spring wheat in the Canadian prairies. Canadian Journal ofSoil Science 86(3):565-572.

Nyiraneza J, Cambouris AN, Ziadi N, Tremblay N, Nolin MC (2012). Spring wheat yield and quality related to soil texture and nitrogen fertilization. Agronomy Journal 104(3):589-599.

Rawluk CDL, Racz GJ, Grant CA (2000). Uptake of foliar N-labelled urea solution at anthesis and its or soil application of 15 effect on wheat grain yield and protein. Canadian Journal of Plant Science 80(2):331-334.

Săulescu NN, Handrea M (1986). Analiza interacțiunilor genotip-mediu în experiențele cu soiuri de grâu [Analysis of genotype-environment interactions in wheat field experiments]. Analele ICCPT Fundulea LIV:9-33.

Singh RP, Trethowan R (2007). Breeding spring bread wheat for irrigated and rainfed production systems of the developing world. In: Kang MS and Priyadarshan PM, editors, Breeding major food staples. Blackwell Publishing, Oxford, UK, pp 107-140.

Staugaitis G, Aleknavičienè LA, Brazienė Z, Marcinkevičius A (2017). The influence of climate conditions and fertilizer rates calculated by different methods on spring wheat crop.Žemès ūkio mokslai 24(4):133-142.

WangJ, Vanga SK, Saxena R, Orsat V, Raghavan V, 2018. Effect ofClimate Change on the Yield of Cereal Crops: A Review. Climate 6(2):41 doi:10.3390/cli6020041.

Woolfolk CW, Raun WR, Johnson GV, Thomason WE, Mullen RW, Wynn KJ, Freeman KW (2002). Influence of late season foliar nitrogen applications on yield and grain nitrogen in winter wheat. Agronomy Journal 94(3):429-434.

Zhang $\mathrm{H}$ and Oweis T (1999). Water-yield relations and optimal irrigation scheduling of wheat in the mediterranean region. Agricultural Water Management 38(3):195-211.

Zhao J, Pu F, Li Y, Xu J, Li N, Zhang Y, Guo J, Pan Z (2017). Assessing the combined effects of climatic factors on spring wheat phenophase and grain yield in Inner Mongolia, China. PloS one 12(11):0185690 